\title{
ANALISIS TINGKAT KESEHATAN KOPERASI PADA KOPERASI SIMPAN PINJAM KOPDIT BENEFACTOR DI KOTA KUPANG
}

\author{
Odilya F. Wetina ${ }^{1}$, Christien C. Foenay ${ }^{2}$, Paulina Y. Amtiran ${ }^{3}$ \\ 1,2,3Universitas Nusa Cendana, odilyawetina@gmail.com; chcfoenay1709@gmail.com; \\ paulinaamtiran@staf.undana.ac.id
}

\begin{abstract}
ABSTRAK
Tujuan penelitian ini adalah untuk menganalisis tingkat kesehatan dan mengetahui faktor-faktor yang mempengaruhi tingkat kesehatan Koperasi Simpan Pinjam (KSP) Koperasi Kredit Benefactor. Penelitian ini menggunakan pendekatan metode deskriptif kuantitatif. Teknik analisis data yang digunakan untuk menganalisis kesehatan koperasi digunakan tujuh variabel yaitu aspek permodalan, kualitas aktiva produktif, manajemen, efisiensi, likuiditas, pertumbuhan dan kemandirian serta aspek jati diri koperasi. Hasil penelitian menunjukkan aspek kualitas aktiva produktif, aspek manajemen, aspek efisiensi dan aspek jati diri koperasi KSP Kopdit Benefactor pada tahun 2016-2018 berada pada predikat sehat. Aspek kemandirian dan pertumbuhan pada tahun 2016 berada pada predikat cukup sehat sementara pada tahun 2017 dan 2018 berada pada predikat kurang sehat. Selanjutnya aspek permodalan pada tahun 2016-2018 berada pada predikat tidak sehat. Hasil penelitian ini dapat memberikan masukan bagi koperasi terutama simpan pinjam agar lebih memperhatikan kebijakan-kebijakan dalam pengelolaan keuangan agar dapat meningkatkan kinerjanya serta meningkatkan pelayanan kepada anggota, sehingga anggota lebih berpatisipasi dalam kegiatan koperasi.
\end{abstract}

Kata Kunci: Kesehatan Koperasi, Kinerja Keuangan, Koperasi, Sehat, Cukup Sehat

\begin{abstract}
The purpose of this study was to analyze the health level and determine the factors that affect the health level of the Benefactor Credit Cooperative (KSP). This study uses a quantitative descriptive method approach. This study uses a quantitative descriptive method approach. The data analysis technique used to analyze the health of the cooperative used seven variables, namely aspects of capital, quality of productive assets, management, efficiency, liquidity, growth and independence as well as aspects of cooperative identity. The results showed that the aspects of the quality of productive assets, aspects of management, aspects of efficiency and aspects of the identity of the Cooperative Cooperative Benefactor cooperative in 2016-2018 were in the healthy predicate. The aspects of independence and growth in 2016 were in the predicate of being quite healthy, while in 2017 and 2018 it was in the predicate of being unhealthy. Furthermore, the capital aspect in 2016-2018 is in the unhealthy predicate. The results of this study can provide input for cooperatives, especially savings and loans so that they pay more attention to policies in financial management in order to improve their performance and improve services to members, so that members participate more in cooperative activities.
\end{abstract}

Keywords: Cooperative Health, Cooperative, Financial Performance, Healthy, Fairly Healthy

Naskah diterima : 19-03-2021 Naskah dipublikasikan: 31-03-2021 


\section{PENDAHULUAN}

Pembangunan ekonomi didasarkan pada demokrasi ekonomi yang mengarahkan bahwa masyarakat harus memegang peran aktif dalam kegiatan pembangunan. Masyarakat Indonesia memiliki tiga pelaku ekonomi yang merupakan sumber usaha ekonomi nasional di kalangan masyarakat yaitu antara lain Badan Usaha Milik Negara (BUMN), Badan Usaha Milik Swasta (BUMS), dan Koperasi. Dari ketiga pelaku ekonomi itu yang diharapkan dapat menjadi tulang punggung perekonomian nasional yaitu Koperasi (Badaruddin, 2005).

Koperasi merupakan salah satu badan usaha yang berbadan hukum dengan usaha yang beranggotakan orang-orang yang berorientasi menghasilkan nilai tambah yang dapat dimanfaatkan bagi peningkatan kesejahteraan anggotanya. Banyak jenis koperasi yang didasarkan pada kesamaan kegiatan dan kepentingan ekonomi anggotanya, seperti Koperasi Produksi, Koperasi Konsumen, Koperasi Jasa, Koperasi Serba Usaha dan Koperasi Simpan Pinjam (Munir dan Indarti, 2012).

Peraturan Menteri Negara Koperasi dan Usaha Kecil dan Menengah Republik Indonesia No.14/Per/M.KUKM/XII/2009, mengemukakan bahwa koperasi simpan pinjam merupakan lembaga koperasi yang melakukan kegiatan usaha menghimpun dana dan menyalurkan dana dari dan untuk anggota, calon anggota, koperasi lain dan atau anggotanya yang perlu dikelola secara professional sesuai dngan prinsip kehati-hatian dan kesehatan koperasi, sehingga dapat meningkatkan kepercayaan dan memberikan manfaat yang sebesar-besarnya kepada anggota dan masyarakat di sekitarnya.

Berhasil tidaknya suatu koperasi tergantung pada bagaimana para anggota dapat bekerja seefektif dan seefisien mungkin pada segi peningkatan keuangan koperasi dan menyusun data tersebut dalam laporan keuangan. Laporan keuangan sendiri terdiri dari neraca dan laporan perhitungan hasil usaha. Melalui laporan keuangan tersebut maka dapat dilihat kondisi kinerja keuangan yang ada pada koperasi tersebut (Hardiningsih, 2013).

Koperasi sebagai perusahaan (cooperative interprise) memerlukan penilaian kinerja sesuai dengan prestasi yang diraihnya secara periodik. Hal ini dimaksudkan agar koperasi dalam melakukan kegiatan operasional usaha baik pembiayaan, investasi dan simpanan sesuai dengan jati diri koperasi sesuai dengan prinsip kehati-hatian sehingga dapat meningkatkan kepercayaan dan memberikan manfaat sebesar-besarnya kepada anggota dan masyarakat disekitarnya mengingat keberhasilan usaha koperasi akan menentukan tingkat kesehatan usahanya (Afandi, 2014).

Penilaian kesehatan koperasi diatur dalam keputusan Menteri Koperasi dan UKM No. 14/Per/M.KUKM/XI/2009. Penilaian ini dilaksanakan selama setahun sekali bagi koperasi yang melaksanakan Rapat Anggota Tahunan (RAT). Penilaian sehat atau tidaknya suatu koperasi dapat dilihat dari beberapa aspek yang terdiri dari aspek permodalan, aspek kualitas aktiva produktif, aspek manajemen, aspek efisiensi, aspek likuiditas, aspek kemandirian dan pertumbuhan, dan aspek jati diri koperasi.

Beberapa penelitian mengenai analisis tingkat kesehatan koperasi telah dilakukan antara lain ; Kamar (2014) ; Manuhutu (2017) dan Putri (2019). Hasil penelitian Kamar (2014) menunjukkan bahwa tingkat kesehatan Koperasi Simpan Pinjam Al-Iklas di Kota Makasar kurang sehat. Hasil yang sama juga ditemukan pada penelitian yang dilakukan oleh Putri (2019) dimana tingkat kesehatan KSP Anugrah Sari berada pada kondisi yang kurang sehat. Di sisi lain penelitian yang dilakukan oleh Manuhutu menemukan bahwa tingkat kesehatan koperasi Wanita Patra di Kota Dumai berada pada predikat cukup sehat. 
Koperasi Simpan Pinjam Kopdit Benefactor merupakan koperasi simpan pinjam yang berada di Kelurahan Kolhua Kecamatan Maulafa Kota Kupang, didirikan secara resmi pada tahun 2006 dengan visi "Menjadi salah satu lembaga keuangan yang sehat, solid dan terpercaya serta dapat memberikan manfaat/ nilai tambah kepada anggota dan masyarakat". Koperasi Simpan Pinjam Kopdit Benefactor di Kolhua Kota Kupang sebagai salah satu lembaga keuangan yang berupaya mencapai visi dan misinya, masih mengalami perkembangan yang lamban di mana jumlah anggota pada saat didirikan terdiri dari 20 orang mengalami peningkatan sampai tahun 2016 sebanyak 130 orang tetapi pada tahun 2018 jumlah anggota mengalami penurunan menjadi 112 orang. Selanjutnya untuk mengetahui perkembangan kinerja keuangan berikut ini disajikan ringkasan laporan keuangan dari KSP Kopdit Benefactor dalam tabel 1 berikut:

Tabel 1. Data Laporan Keuangan KSP Kopdit Benefactor

\begin{tabular}{ccccc}
\hline Tahun & Total Asset & Modal Sendiri & Pendapatan & SHU \\
\hline 2016 & 465.923 .022 & 457.217 .622 & 44.082 .730 & 40.257 .750 \\
2017 & 503.364 .644 & 468.631 .258 & 41.693 .762 & 37.118 .762 \\
2018 & 521.824 .411 & 481.632 .210 & 41.130 .500 & 36.654 .300 \\
\hline
\end{tabular}

Sumber: Laporan Neraca Kopdit Benefactor 2016-2018

Tabel 1 menunjukkan bahwa total asset dan modal sendiri pada KSP Kopdit Benefactor mengalami kenaikan setiap tahun. Namun hal yang menjadi masalah berdasarkan tabel 1 menunjukkan bahwa total aset dan modal sendiri meningkat sedangkan pendapatan dan SHU menurun, di mana persentase penurunan pendapatan pada tahun 2017 5,42\% dan SHU menurun 7,80\%, sedangkan pada tahun 2018 pendapatan menurun 35\% dan SHU menurun1,25\%. Masalah penurunan pendapatan dan SHU pada KSP Kopdit Benefactor tidak hanya dipengaruhi oleh faktor pemanfaatan modal yang kurang baik akan tetapi dapat dipengaruhi oleh beberapa faktor lain.

Berdasarkan uraian di atas penulis bermaksud untuk mengetahui lebih jauh tentang KSP Kopdit Benefactor dan penulis tertarik untuk melakukan penelitian dengan judul "Analisis Tingkat Kesehatan Koperasi pada KSP Kopdit Benefactor di Kolhua Kota Kupang”.

\section{KAJIAN LITERATUR Kinerja Keuangan}

Definisi kinerja menurut Wibowo (2007), merupakan tentang melakukan pekerjaan dan hasil yang dicapai dari pekerjaan tersebut. Menurut Fahmi (2011), kinerja keuangan adalah suatu analisis yang dilakukan untuk melihat sejauh mana suatu perushaan telah melaksanakan dengan menggunakan aturan-aturan pelaksanaan keuangan secara baik dan benar.

Kinerja keuangan koperasi berdasarkan penelitian Nurmala dan Yuniarti (2013) dapat dilihat dari kemampuannya dalam menata, mengatur, membagi dan menempatkan dana koperasinya dengan tepat, sehingga dapat menjamin kelangsungan koperasi baik jangka pendek maupun jangka panjang.

Kinerja keuangan adalah hasil atau prestasi yang telah dicapai oleh manajemen perusahaan dalam menjalankan fungsinya mengelola aset perusahaan secara efektif selama periode tertentu. Kinerja keuangan sangat dibutuhkan perusahaan untuk mengetahui dan mengevaluasi sampai di mana tingkat keberhasilan perusahaan berdasarkan aktivitas keuangan yang telah dilaksanakan (Rudianto, 2013). 
UU No. 25 Tahun 1992 menyatakan bahwa kinerja keuangan adalah salah satu bentuk penilaian dengan asas manfaat dan efisiensi dalam penggunaan anggaran keuangan. Sehingga penilaian terhadap kinerja keuangan menjadi sangat penting di berbagai macam usaha khususnya perkoperasian. Penilaian kinerja keuangan digunakan perusahaan supaya kegiatan operasionalnya lebih baik terutama pada bagian keuangannya.

\section{Laporan Keuangan}

Definisi laporan keuangan sebagaimana dikemukakan oleh Munawir (2017) pengertian laporan keuangan adalah hasil dari proses akuntansi yang dapat digunakan sebagai alat untuk berkomunikasi antara data keuangan atau aktivitas suatu perusahaan dengan pihak-pihak yang berkepentingan dengan data atau aktivitas perusahaan tersebut.

Laporan keuangan merupakan hasil akhir dari proses akuntansi yang meliputi dua laporan utama yakni Neraca dan laporan Laba Rugi (Sustrisno, 2016). Menurut Kasmir (2011) berpendapat bahwa laporan keuangan adalah laporan yang menunjukkan kondisi keuangan dengan perusahaan pada saat ini atau dalam suatu periode tertentu. Laporan keuangan disusun dengan maksud untuk menyediakan informasi keuangan suatu perusahaan kepada pihak-pihak yang berkepentingan sebagai bahan pertimbangan di dalam mengambil keputusan (Harahap, 2009). Menurut Sugiono dan Untung (2008), laporan keuangan koperasi merupakan hasil akhir dari kegiatan akuntansi (siklus akuntansi) yang mencerminkan kondisi keuangan dan hasil operasi koperasi.

\section{Koperasi}

Koperasi adalah perkumpulan manusia seorang-perorangan yang dengan sukanya sendiri hendak bekerja sama untuk memajukan ekonominya Razak (2012). Selain itu, (Mutis, 2001) menyatakan bahwa koperasi adalah suatu perkumpulan dari orang-orang atas dasar persamaan derajat sebagai manusia, dengan tidak memandang haluan agama dan politik secara suka rela masuk untuk sekedar memenuhi kebutuhan bersamanya yang bersifat keberadaan atas tanggungan bersama.

Menurut Widiyanti (2012), koperasi dilahirkan sebagai badan usaha dengan tujuan untuk memajukan kepentingan ekonomi dari anggota-anggotanya, dan koperasi diberikan suatu pengertian sebagai sebuah organisasi yang berwatak sosial, dikarenakan koperasi selalu menampakkan wataknya yang selalu cenderung untuk membela diri, menunjukkan ciri-ciri manusiawinya yang kuat dan menjunjung tinggi keadilan dan kemerataan.

\section{Koperasi Simpan Pinjam}

Koperasi simpan pinjam atau koperasi jasa keuangan adalah koperasi yang bergerak di sektor keuangan dengan aktivitasnya melakukan simpan pinjam. Sumber dana diperoleh dari anggota yang berupa simpanan pokok, simpanan wajib, maupun dari sumber lain seperti dari lembaga keuangan perbankan. Dana yang dihimpun oleh koperasi disalurkan kembali kepada anggota atau para calon anggota. Atas penyaluran dana tersebut koperasi mendapatkan pendapatan berupa pendapatan bunga (Sudarwanto, 2013).

Koperasi simpan pinjam merupakan usaha penyimpanan dan peminjaman sejumlah uang untuk keperluan para anggotanya atau koperasi yang menyediakan dana bagi orang yang memerlukan. Koperasi simpan pinjam memberi pinjaman uang kepada anggotanya yang memerlukan bantuan dengan persyaratan ringan, mudah, dan terjamin (Karsono, 2005). Koperasi simpan pinjam merupakan usaha penyimpanan dan peminjaman sejumlah uang untuk keperluan para anggotanya atau koperasi yang menyediakan dana bagi orang yang memerlukan. Koperasisi simpan pinjam memberi pinjaman uang kepada anggotanya yang memerlukan bantuan dengan persyaratan ringan, mudah, dan terjamin (Karsono, 2005). 


\section{Kesehatan Koperasi}

Ruang lingkup penilaian kesehatan koperasi meliputi penilaian beberapa aspek anatara lain permodalan, kualitas aktiva produktif, manajemen, efisiensi, likuiditas, kemandirian dan pertumbuhan, dan jati diri koperasi. Penilaian kesehatan koperasi membantu koperasi dalam menyajikan informasi keuangan yang akan digunakan sebagai dasar pengambilan keputusankeputusan ekonomi oleh berbagai pihak yang terkait dengan koperasi tersebut. Adapun pihak yang memerlukan informasi akuntansi koperasi meliputi pengurus, anggota dan kreditur (Baswir, 2012).

\section{Permodalan}

Permodalan merupakan dana yang akan digunakan untuk melaksanakan usaha-usaha koperasi. Arti modal lebih ditekankan kepada nilai, daya beli, atau kekuasaan untuk menggunakan apa yang terkandung dalam barang modal (Hendrojogi, 2004). Hendar (2010) menyatakan bahwa sumber-sumber permodalan koperasi dapat berasal dari simpanan pokok, simpanan wajib, dana cadangan, hibah dan lain-lain. Aspek permodalan yang digunakan yaitu rasio modal sendiri terhadap total aset. Modal sendiri koperasi adalah jumlah dari simpanan pokok, simpanan wajib, hibah, cadangan yang disisihkan dari sisa hasil usaha. Rasio modal sendiri terhadap total aset maksudnya untuk mengukur kemampuan modal tetap koperasi dalam mendukung pendanaan terhadap total aset.

\section{Kualitas Aktiva Produktif}

Aktiva produktif adalah kekayaan koperasi yang mendatangkan penghasilan bagi koperasi. Aktiva produktif meliputi kreditt yang diberikan, surat-surat berharga, penempatan pada bank lain, penyertaan, tagihan lainnya, dan rekening administratif (Simon, 2004). Aspek kualitas aktiva produktif yang dinilai yaitu rasio volume pinjaman pada anggota terhadap total volume pinjaman diberikan. Volume pinjaman anggota adalah pinjaman koperasi yang berasal dari pinjaman anggota. Sedangkan volume pinjaman adalah semua pinjaman koperasi yang berasal dari anggota, koperasi lainnya, bank, dan lembaga keuangan lainnya, penerbitan obligasi dan surat hutang lainnya serta sumber yang sah.

\section{Manajemen}

Pengertian manajemen dapat menunjuk kepada orang/ sekelompok orang, atau bisa juga merupakan proses. Manajemen dalam koperasi terdiri dari rapat anggota, pengurus, dan manajer. Ada hubungan timbal balik antara ketiga unsur tersebut, dalam arti bahwa tidak satu unsur pun bisa bekerja secara efektif tanpa dibantu atau didukung oleh unsur-unsur lainnya (Hendrojogi, 2004). Aspek manajemen yang dinilai yaitu manjemen umum. Manajemen umum adalah aspek yang didalamnya berisi tentang tata tertib, visi misi, tujuan, dan rencana kerja seperti pengurus, pengawas, dan pengelola koperasi.

\section{Efisiensi}

Efisiensi dalam koperasi dapat diartikan juga sebagai suatu usaha pencapaian keuntungan maksimum dengan memperhatikan berbagai kendala yang ditentukan dalam rapat keputusan anggota (Hendar, 2005). Penilaian efisiensi koperasi yang digunakan yaitu rasio beban operasi anggota terhadap partisipasi bruto. Beban operasi anggota adalah beban pokok ditambah dengan beban usaha ditambah beban perkoperasian yang dikeluarkan untuk aktivitas kopearsi. Sedangkan partisipasi bruto adalah jumlah pendapatan yang diperoleh dari partisipasi anggota terhadap koperasi dalam waktu tertentu, sebelum dikurangi beban pokok.

\section{Likuiditas}

Likuiditas berhubungan dengan kemampuan suatu perusahaan untuk memenuhi kewajiban jangka pendeknya yang segera jatuh tempo, yang segera harus dipenuhi. Dalam hal ini adalah kemampuan koperasi untuk memenuhi kewajiban jangka pendek. Jumlah alat-alat 
pembayaran (alat-alat likuid) yang dimiliki suatu perusahaan pada suatu saat tertentu merupakan kekuatan membayar dari perusahaan yang bersangkutan (Hery, 2015).

Penilaian aspek likuiditas yang digunakan yaitu rasio kas ditambah bank terhadap kewajiban lancar. Kas adalah alat pembayaran milik koperasi yang siap dan bebas digunakan untuk membiayai kegiatan umum koperasi. Sedangkan bank adalah sisa rekening bank milik koperasi yang siap dan bebas digunakan untuk membiayai kegiatan umum koperasi. Kewajiaban lancar adalah kewajiban atau hutang jangka pendek (Suryani, 2008).

\section{Kemandirian dan Pertumbuhan}

Peraturan Menteri Negara Koperasi dan Usaha Kecil Menengah RI No.20/Per/M.KUKM/XI/2008 dijelaskan bahwa kemandirian dan pertumbuhan koperasi merujuk pada bagaimana koperasi dalam melayani masyarakat secara mandiri dan seberapa besar pertumbuhan koperasi di tahun yang bersangkutan dibanding dengan tahun sebelumnya. Penilaian terhadap aspek kemandirian dan pertumbuhan yang digunakan yaitu rasio rentabilitas aset. Rentabilitas asset merupakan perbandingan antara Sisa Hasil Usaha (SHU) dengan total asset. SHU sebelum pajak merupakan hasil selisih antara penghasilan yang diterima koperasi selama periode tertentu dengan beban yang dikeluarkan untuk memperoleh penghasilan, yang belum dikenakan pajak.

\section{Jati Diri Koperasi}

Penelitian aspek jati diri koperasi dimaksudkan untuk mengukur keberhasilan koperasi dalam mencapai tujuannya yaitu mempromosikan ekonomi anggota. Koperasi secara sadar tetap bertujuan untuk memajukan kepentingan anggotanya dan melakukan upaya yang membuktikan bahwa koperasi telah memajukan kepentingan anggotanya (Soedjono, 2007). Penilaian Aspek jati diri koperasi rasio pasrtisipasi bruto. Rasio partisipasi bruto adalah tingkat kemampuan koperasi dalam melayani anggota, semakin tinggi atau besar persentasenya semakin baik. Partisipasi bruto adalah kontribusi anggota kepada koperasi sebagai imbalan penyerahan jasa pada anggota yang mencakup beban pokok dan partisipasi netto.

\section{METODE PENELITIAN}

Jenis penelitian ini merupakan penelitian deskriptif kuantitatif yaitu penelitian yang mendeskripsikan mengenai objek dan kondisi koperasi berdasarkan data tahun 2016-2018 degan rujukan teori untuk mengetahui kinerja keuangan dan kesehatan koperasi. Pendekatan penelitian adalah studi kasus, yaitu melakukan secara detail dan lengkap mengenai suatu objek yang dipilih yakni KSP Kopdit Benefactor yang berada di Kolhua Kota Kupang.

Jenis data yang digunakan adalah data kualitatif yang berupa sejarah dan perkembangan koperasi, struktur serta visi-misi dan tujuan KSP Kopdit Benefactor. Data kuantitatif yang digunakan berupa laporan neraca dan sisa hasil usaha KSP Kopdit Benefactor. Sumber data yang digunakan dalam penelitian ini yaitu data primer yang diperoleh berupa hasil wawancara dengan kepala atau manajer KSP Kopdit Benefactor. Data sekunder yang digunakan berupa laporan neraca dan sisa hasil usaha KSP Kopdit Benefactor tahun 2016-2018.

Teknik analisis data yang digunakan adalah analisis kesehatan koperasi berdasarkan kriteria penilaian dari Peraturan Menteri Negara Koperasi dan Usaha Kecil dan Menengah No.14/Per/M.KUKM/XII/2009. 


\section{HASIL DAN PEMBAHASAN}

\section{Hasil Analisis Aspek-Aspek Kesehatan Koperasi}

Hasil analisis aspek-aspek kesehatan KSP Kopdit Benefactor tahun 2016-2018 berdasarkan kriteria penilaian dari Peraturan Menteri Negara Koperasi dan Usaha Kecil dan Menengah No.14/Per/M.KUKM/XII/2009.

\section{Permodalan}

Penilaian terhadap aspek permodalan dalam penelitian ini dilakukan menggunakan satu rasio perhitungan modal yakni rasio modal sendiri terhadap total aset. Hasil perhitungan rasio modal sendiri terhadap total aset pada KSP Kopdit Benefactor pada tahun 2016-2018 dapat dilihat pada tabel 2 berikut :

Tabel 2. Perhitungan Rasio Modal Sendiri terhadap Total Aset pada KSP Kopdit Benefactor

\begin{tabular}{ccccccc}
$\begin{array}{c}\text { Tahun } \\
(1)\end{array}$ & $\begin{array}{c}\text { Modal } \\
\text { Sendiri } \\
(2)\end{array}$ & \multicolumn{1}{c}{$\begin{array}{c}\text { Total Aset } \\
(3)\end{array}$} & $\begin{array}{c}(2 / 3) \times 100 \% \\
(4)\end{array}$ & $\begin{array}{c}\text { Nilai } \\
(5)\end{array}$ & $\begin{array}{c}\text { Bobot } \\
(\%) \\
(6)\end{array}$ & $\begin{array}{c}\text { Skor } \\
(7)\end{array}$ \\
\hline 2016 & 457.217 .295 & $\begin{array}{l}485.932 .02 \\
2\end{array}$ & $94.09 \%$ & 25 & 6 & 1,50 \\
2017 & 468.631 .258 & $\begin{array}{l}503.384 .64 \\
4\end{array}$ & $93,09 \%$ & 25 & 6 & 1,50 \\
2018 & 481.623 .210 & $\begin{array}{l}521.924 .41 \\
1\end{array}$ & $92,28 \%$ & 25 & 6 & 1,50 \\
\hline
\end{tabular}

Sumber: Data diolah, 2020

Tabel 2 menunjukkan hasil analisis perhitungan rasio modal sendiri terhadap total aset pada KSP Kopdit Benefactor tahun 2016-2018 yakni sebesar 94,09\%, 93,09\%, dan 92,28\% berada pada kategori rasio $80 \leq \mathrm{x}<100$ mendapat nilai sebesar 25 dengan skor 1,50 . Jika 1,50 yang merupakan skor yang diperoleh KSP Kopdit Benefactor dibagi dengan 6 yang merupakan bobot maksimal untuk rasio modal sendiri terhadap total aset dan kemudian dikali dengan $100 \%$, hasilnya adalah $25 \%$ masuk dalam kategori rangenya $20 \leq \mathrm{x}<40$ dengan predikat tidak sehat.

2. Kualitas Aktiva Produktif

Penilaian terhadap kualitas aktiva produktif dalam penelitian ini menggunakan satu rasio yaitu rasio volume pinjaman pada anggota terhadap volume pinjaman diberikan. Hasil perhitungan rasio volume pinjaman pada anggota terhadap volume pinjaman diberikan pada KSP Kopdit Benefactor pada tahun 2016-2018 dapat dilihat pada tabel 3 berikut :

Tabel 3. Perhitungan Rasio Volume Pinjaman pada Anggota terhadap Volume Pinjaman diberikan pada KSP Kopdit Benefactor

\begin{tabular}{ccccccc}
\hline Tahun & $\begin{array}{c}\text { Volume } \\
\text { Pinjaman } \\
\text { pada } \\
\text { Anggota } \\
(2)\end{array}$ & $\begin{array}{c}\text { Volume } \\
\text { Pinjaman } \\
\text { Diberikan } \\
(3)\end{array}$ & $\begin{array}{l}(2 / 3) \times 100 \\
(1)\end{array}$ & $\begin{array}{l}\text { Nila } \\
\text { i }\end{array}$ & $\begin{array}{c}\text { Bobot } \\
(\%)\end{array}$ & Skor \\
\hline 2016 & 301.045 .000 & $\begin{array}{c}226.000 .00 \\
0\end{array}$ & $133,21 \%$ & 100 & 10 & 10 \\
2017 & 377.508 .860 & $\begin{array}{c}302.500 .00 \\
0\end{array}$ & $124,80 \%$ & 100 & 10 & 10 \\
2018 & 240.079 .000 & $\begin{array}{c}132.000 .00 \\
0\end{array}$ & $181,88 \%$ & 100 & 10 & 10 \\
\hline
\end{tabular}

Sumber: Data diolah, 2020 
Tabel 3 menunjukkan hasil analisis perhitungan rasio volume pinjaman pada anggota terhadap volume pinjaman diberikan pada KSP Kopdit Benefactor pada tahun 2016-2018 yakni $133,21 \%, 124,80 \%$ dan 181,88\% melebihi dari pada rasio 75\%, maka diberi nilai 100 dengan perolehan skor 10. Jika 10 yang merupakan skor yang diperoleh KSP Kopdit Benefactor dibagi dengan 10 yang merupakan bobot maksimal untuk rasio volume pada anggota terhadap volume pinjaman diberikan dibagikan dikali dengan $100 \%$, hasilnya adalah $100 \%$ masuk dalam kategori rangenya $80 \leq \mathrm{x}<100$ dengan predikat sehat.

3. Manajemen

Penilaian manajemen dalam penelitian ini adalah bagian manajemen umum. Dalam manajemen umum terdapat 12 pertanyaan yang diisi dengan jawaban "Ya" dan "Tidak" dengan skor yang telah ditentukan. Hasil analisis manajemen umum pada KSP Kopdit Benefactor pada tahun 2016-2018 dapat dilihat pada tabel 4 berikut :

Tabel 4. Perhitungan Rasio Manajemen Umum

\begin{tabular}{ccc}
\hline Tahun & Jumlah Jawaban Ya & Skor \\
\hline 2016 & 12 & 3,00 \\
2017 & 12 & 3,00 \\
2018 & 12 & 3,00 \\
\hline
\end{tabular}

Sumber: Data diolah, 2020

Tabel 4. menunjukkan hasil analisis perhitungan rasio manajemen umum pada KSP Kopdit Benefactor pada tahun 2016-2018 memperoleh skor 3,00. Jika 3,00 yang merupakan skor yang diperoleh pada KSP Kopdit Benefactor dibagi dengan 3 yang merupakan bobot maksimal untuk rasio manajemen umum dan dikali $100 \%$, hasilnya adalah $100 \%$ masuk dalam kategori rangenya $80 \leq \mathrm{x} \leq 100$ dengan predikat sehat.

4. Efisiensi

Penilaian terhadap efisiensi yang dilakukan dalam penelitian ini dengan menggunakan rasio beban operasi anggota terhadap partisipasi bruto. Hasil perhitungan rasio beban operasi anggota terhadap partisipasi bruto pada KSP Kopdit Benefactor pada tahun 2016-2018 dapat dilihat pada tabel 5 berikut :

Tabel 5. Perhitungan Rasio Beban Operasi Anggota terhadap Partisipasi Bruto

\begin{tabular}{|c|c|c|c|c|c|c|}
\hline Tahun & $\begin{array}{c}\text { Beban } \\
\text { Operasi } \\
\text { Anggota } \\
(2)\end{array}$ & $\begin{array}{l}\text { Partisipasi } \\
\text { Buto }\end{array}$ & $(2 / 3) \times 100 \%$ & Nilai & $\begin{array}{c}\text { Bobot } \\
(\%)\end{array}$ & Skor \\
\hline 2016 & 4.476 .200 & $\begin{array}{c}40.405 .25 \\
0\end{array}$ & $11,08 \%$ & 100 & 4 & 4 \\
\hline 2017 & 4.573 .000 & $\begin{array}{c}37.322 .50 \\
0\end{array}$ & $12,25 \%$ & 100 & 4 & 4 \\
\hline 2018 & 3.825 .000 & $\begin{array}{c}39.547 .50 \\
0\end{array}$ & $9,67 \%$ & 100 & 4 & 4 \\
\hline
\end{tabular}

Sumber: Data diolah, 2020

Tabel 5 menunjukkan hasil analisis perhitungan Rasio Beban Operasi Anggota Terhadap Partisipasi Bruto pada KSP Kopdit Benefactor pada tahun 2016-2018 yakni 11,08\%, 12,25\% dan 9,67\% masuk dalam kategori rasio <90 maka dari itu nilai yang diperoleh adalah 100 . Jika 4,00 yang merupakan skor yang diperoleh KSP Kopdit Benefactor dibagi 4 yang merupakan bobot maksimal untuk rasio beban operasi anggota terhadap partisipasi bruto dan 
dikali $100 \%$, hasilnya adalah $100 \%$ dan masuk dalam kategori rangenya $80 \leq x \leq 100$ dengan predikat sehat.

5. Likuiditas

Penilaian terhadap likuiditas yang dilakukan dalam penelitian ini dengan satu rasio yaitu rasio Kas Bank terhadap kewajiban lancar. Hasil perhitungan Kas Bank terhadap kewajiban lancar pada KSP Kopdit Benefactor pada tahun 2016-2018 dapat dilihat pada tabel 6 berikut :

Tabel 6. Perhitungan Rasio Kas Bank terhadap Kewajiban Lancar

\begin{tabular}{|c|c|c|c|c|c|c|}
\hline $\begin{array}{c}\text { Tahun } \\
\text { (1) }\end{array}$ & $\begin{array}{c}\text { Kas + } \\
\text { Bank } \\
\text { (2) }\end{array}$ & $\begin{array}{l}\text { Kewajiban } \\
\text { Lancar } \\
\text { (3) }\end{array}$ & $\begin{array}{c}(2 / 3) \times 100 \% \\
\text { (4) }\end{array}$ & $\begin{array}{l}\text { Nilai } \\
\text { (5) }\end{array}$ & $\begin{array}{c}\text { Bobot (\%) } \\
(6)\end{array}$ & $\begin{array}{c}\text { Sko } \\
\text { r } \\
\text { (7) }\end{array}$ \\
\hline 2016 & $\begin{array}{c}177.937 .02 \\
2\end{array}$ & 28.714 .725 & $619,67 \%$ & 25 & 10 & 2,5 \\
\hline 2017 & $\begin{array}{c}117.325 .78 \\
4\end{array}$ & 34.753 .386 & $337,60 \%$ & 25 & 10 & 2,5 \\
\hline 2018 & $\begin{array}{c}273.345 .41 \\
1\end{array}$ & 40.201 .201 & $679,94 \%$ & 25 & 10 & 2,5 \\
\hline
\end{tabular}

Sumber: Data diolah, 2020

Tabel 6 menunjukkan hasil analisis perhitungan rasio Kas Bank terhadap kewajiban lancar pada KSP Kopdit Benefactor pada tahun 2016-2018 diberi nilai 25 karena rasio 619,67\%, $337,60 \%$ dan $679,94 \%$ masuk dalam kategori rasio >200 maka dari itu nilai yang diperoleh adalah 25 dengan skor yang diperoleh 2,5. Jika 2,5 yang merupakan skor yang diperoleh KSP dibagi dengan 10 yang merupakan bobot maksimal untuk rasio Kas Bank terhadap kewajiban lancar dan dikali $100 \%$, hasilnya adalah $25 \%$ masuk dalam kategori rangenya $20 \leq$ $\mathrm{x}<40$ dengan predikat tidak sehat.

6. Kemandirian dan Pertumbuhan

Penilaian terhadap kemandirian dan pertumbuhan yang dilakukan dalam penelitian ini dengan satu rasio yaitu rasio rentabilitas asset. Hasil perhitungan rasio rentabilitas asset pada KSP Kopdit Benefactor pada tahun 2016-2018 dapat dilihat pada tabel 7 berikut :

Tabel 7. Perhitungan Rasio Rentabilitas Aset

\begin{tabular}{ccccccc}
\hline Tahun & $\begin{array}{c}\text { SHU } \\
\text { Sebelum } \\
\text { Pajak } \\
(2)\end{array}$ & Total Aset & $(2 / 3) \times 100 \%$ & Nilai & $\begin{array}{c}\text { Bobot } \\
(\%)\end{array}$ & Skor \\
& $(3)$ & $(4)$ & $(5)$ & $(6)$ & $(7)$ \\
\hline 2016 & $\begin{array}{c}40.257 .73 \\
0\end{array}$ & $\begin{array}{c}485.932 .02 \\
2\end{array}$ & $8,28 \%$ & 75 & 3 & 2,25 \\
2017 & $\begin{array}{c}37.118 .76 \\
2\end{array}$ & $\begin{array}{c}503.384 .64 \\
4\end{array}$ & $7,37 \%$ & 50 & 3 & 1,50 \\
2018 & $\begin{array}{c}36.654 .30 \\
0\end{array}$ & $\begin{array}{c}521.974 .41 \\
1\end{array}$ & $7,02 \%$ & 50 & 3 & 1,50 \\
\hline
\end{tabular}

Sumber: Data diolah, 2020

Tabel 7 menunjukkan hasil analisis perhitungan rasio rentabilitas aset pada KSP Kopdit Benefactor pada tahun 2016 sebesar 8,28\% mendapat nilai 75 karena rasio tersebut masuk ke dalam kategori rasio 7,5<x $\leq 10$. Sedangkan untuk tahun 2017 dan 2018 mendapat nilai 50 karena rasio 7,37 dan 7,02\% pada tahun 2017 dan 2018 masuk dalam kategori rasio $5<\mathrm{x}$ 
$\leq 7,5$. Jika 2,25 skor yang diperoleh pada tahun 2016 dan 1,50 skor yang diperoleh pada tahun 2017 dan 2018 pada KSP Kopdit Benefactor dibagi dengan 3 yang merupakan bobot maksimal untuk rasio rentabilitas aset dan dikali $100 \%$, hasilnya adalah $75 \%$ pada tahun 2016 masuk dalam kategori rangenya $60 \leq \mathrm{x}<80$ dengan predikat cukup sehat sedangkan pada tahun 2017 dan 2018 hasilnya adalah 50\% masuk dalam kategori rangenya $40 \leq x<600$ dengan predikat kurang sehat.

7. Jati Diri Koperasi

Penilaian terhadap jati diri koperasi dalam penelitian ini dilakukan dengan satu rasio yaitu rasio partisipasi bruto. Hasil perhitungan rasio partisipasi bruto pada KSP Kopdit Benefactor pada tahun 2016-2018 dapat dilihat pada tabel 8 berikut:

Tabel 8. Perhitungan Rasio Partisipasi Bruto pada KSP Kopdit Benefactor

\begin{tabular}{ccccccc}
\hline Tahun & $\begin{array}{c}\text { Partisipasi } \\
\text { Bruto } \\
(2)\end{array}$ & $\begin{array}{c}\text { Partisipasi } \\
\text { Bruto } \\
\text { +Pendapatan } \\
(3)\end{array}$ & $\begin{array}{c}(2 / 3) \\
\times 100 \%\end{array}$ & $\begin{array}{c}\text { Nilai } \\
(4)\end{array}$ & $\begin{array}{c}\text { Bobot } \\
(\%)\end{array}$ & Skor \\
\hline 2016 & $\begin{array}{c}40.405 .25 \\
0\end{array}$ & 44.082 .730 & $91,66 \%$ & 100 & 7 & 7 \\
2017 & $\begin{array}{c}37.322 .50 \\
0\end{array}$ & 41.693 .762 & $89,52 \%$ & 100 & 7 & 7 \\
2018 & $\begin{array}{c}39.547 .50 \\
0\end{array}$ & 41.130 .500 & $96,15 \%$ & 100 & 7 & 7 \\
\hline
\end{tabular}

Sumber: Data diolah, 2020

Tabel 8 menunjukkan hasil analisis perhitungan rasio partisipasi bruto pada KSP Kopdit Benefactor pada tahun 2016-2018 diberi nilai 100 karena rasio 91,66\%, 89,52\% dan 96,15\% masuk dalam kategori rasio $\geq 75$ maka dari itu nilai yang diperoleh adalah 100 dengan skor 7 . Jika 7 yang merupakan skor yang diperoleh KSP Kopdit Benefactor dibagi dengan 7 yang merupakan bobot maksimal untuk rasio partisipasi bruto dan dikali dengan $100 \%$, hasilnya adalah $100 \%$ masuk dalam kategori $80 \leq \mathrm{x}<100$ dengan predikat sehat.

\section{Pembahasan}

Berdasarkan hasil penelitian tingkat kesehatan KSP Kopdit Benefactor pada tahun 2016-2018 ditunjukkan pada tabel 9 berikut:

Tabel 9. Tingkat Kesehatan KSP Kopdit Benefactor Tahun 2016-2018

\begin{tabular}{|c|c|c|c|}
\hline \multirow{2}{*}{ Aspek Kesehatan Koperasi } & \multicolumn{3}{|c|}{ Tahun } \\
\cline { 2 - 4 } & 2016 & 2017 & 2018 \\
\hline Permodalan & Tidak Sehat & Tidak Sehat & Tidak Sehat \\
\hline Aktiva Kualitas Produktif & Sehat & Sehat & Sehat \\
\hline Manajemen & Sehat & Sehat & Sehat \\
\hline Efisiensi & Sehat & Sehat & Sehat \\
\hline Likuiditas & Tidak Sehat & Tidak Sehat & Tidak Sehat \\
\hline $\begin{array}{c}\text { Kemandirian dan } \\
\text { Pertumbuhan }\end{array}$ & Cukup Sehat & Kurang Sehat & $\begin{array}{c}\text { Kurang } \\
\text { Sehat }\end{array}$ \\
\hline Jati Diri Koperasi & Sehat & Sehat & Sehat \\
\hline
\end{tabular}

Sumber : Hasil Olah Data, 2021

Hasil analisis tingkat kesehatan pada KSP Kopdit Benefactor pada tahun 2016-2018 penilaian aspek permodalan dari rasio modal sendiri terhadap total aset berada pada predikat tidak sehat. Hasil penelitian ini dapat diketahui bahwa modal sendiri KSP Kopdit Benefactor 
belum maksimal dalam mendanai total aset yang dimilikinya. Hasil penelitian ini sejalan dengan penelitian Putra (2017) dimana rasio modal sendiri terhadap total aset belum memenuhi standar yang ditetapkan.

Penilaian aspek kualitas aktiva produktif dari rasio volume pinjaman pada anggota terhadap volume pinjaman yang diberikan berada pada predikat sehat. Hal ini dapat diketahui bahwa koperasi simpan pinjam sangat baik dalam memenuhi seluruh pinjaman kepada anggotanya. Hasil ini sama dengan penelitian yang dilakukan oleh Putri (2019).

Penilaian aspek manajemen dari rasio manajemen umum berada pada predikat sehat. Hal ini menunjukkan bahwa koperasi simpan pinjam mampu mengelola manajemen secara efektif dan efisien sehingga kegiatan usaha di masa depan dapat mencapai tujuan yang diharapkan.

Penilaian aspek efisiensi dari rasio beban operasi anggota terhadap partispasi bruto berada pada predikat sehat. Hal ini menunjukkan bahwa kondisi koperasi simpan pinjam dalam hal ini sudah baik karena partisipasi bruto mampu menutupi kerugian yang diakibatkan dari beban operasi anggota yang ada. Penilaian aspek likuiditas dari rasio Kas Bank terhadap kewajiban berada pada predikat tidak sehat.Hal ini disebabkan oleh kas dan bank yang ada terlalu berlebihan dan kurang produktif atau menganggur sehingga kurang baik bagi perkembangan koperasi selanjutnya.

Penilaian aspek kemandirian dan pertumbuhan dari rasio rentabilitas aset pada tahun 2016 cukup sehat. Sedangkan pada tahun 2017 dan 2018 berada pada predikat kurang sehat. Hasil penelitian ini menunjukkan bahwa koperasi simpan pinjam dalam perolehan SHU dengan memanfaatkan total aset yang dimilikinya masih tergolong buruk. Kemampuan koperasi dalam mengelola modal untuk menghasilkan laba mengalami penurunan. Selain itu, menunjukkan bahwa kemampuan aset koperasi untuk menghasilkan pendapatan masih belum optimal. Hal ini disebabkan karena peningkatan dan penurunan SHU sebelum pajak belum sebanding dengan peningkatan total aset koperasi.

Penilaian aspek jati diri koperasi dari rasio partisipasi bruto berada pada predikat sehat. Hal ini menunjukkan bahwa KSP Kopdit Benefactor dalam mengaktifkan anggotanya perihal simpan pinjam tergolong baik. Hal tersebut terbukti dengan adanya kontribusi anggota dalam perolehan partisipasi bruto dan pendapatan lainnya. Hasil penelitian ini sejalan dengan hasil penelitian yang dilakukan oleh Syaifudin (2017) ; Putra (2017) dan Putri (2019). Hasil penelitian ini menunjukkan bahwa aspek kesehatan yang memiliki kontribusi rendah terhadap tingkat kesehatan KSP Kopdit Benefactor adalah aspek permodalan, aspek kemandirian dan pertumbuhan serta aspek likuiditas.

\section{PENUTUP \\ Simpulan}

Kesehatan Koperasi pada KSP Kopdit Benefactor pada tahun 2016-2018 dapat disimpulkan bahwa aspek kualitas aktiva produktif, aspek manajemen, aspek efisiensi dan aspek jati diri koperasi berada pada predikat Sehat. Aspek kemandirian dan pertumbuhan pada tahun 2016 berada pada predikat cukup sehat sedangkan pada tahun 2017 dan 2018 berada pada predikat kurang sehat. Selanjutnya aspek permodalan dan aspek likuiditas berada pada predikat tidak sehat. Keterbatasan penelitian ini adalah hanya menggunakan satu koperasi sebagai subyek penelitian. 


\section{Saran}

Dari Aspek permodalan untuk meningkatkan modal sendiri salah satu cara yang dilakukan adalah dengan meningkatkan nilai simpanan wajib. Dan juga koperasi wajib untuk mengelola dana tersebut agar mendatangkan manfaat bagi para anggota. Dari kondisi likuiditas dan aspek kemandirian dan pertumbuhan yang sangat buruk dikarenakan terlalu tingginya aktiva lancar atau aset yang dimilikinya, maka sebaiknya koperasi harus lebih efektif dalam mengelola aktiva lancar atau aset yang dimiliki dengan cara menyalurkan dana tersebut ke anggota atau nasabah dalam bentuk pinjaman agar dana tersebut tidak menganggur dan juga dapat menghasilkan laba atau sisa hasil usaha yang maksimal sehingga dapat mengembangkan usaha koperasinya di masa yang akan datang dengan lebih baik.

Diharapkan hasil penelitian ini dapat dipakai sebagai acuan bagi peneliti selanjutnya untuk mengembangkan penelitian ini dengan menggunakan kombinasi analisis kinerja keuangan lain yang dapat digunakan untuk mengetahui kesehatan koperasi.

\section{REFERENSI}

Afandi, Pandi. 2014. Analisis Kinerja Keuangan untuk Mengukur Kesehatan Keuangan Koperasi KSU BMT Arafah Kecamatan Bancak Kabupaten Semarang. Jurnal Among Makarti, Vol 7 No.13.

Baddarudin, 2005. Modal sosial dan pemberdayaan komunitas Nelayan (Isu-isu Kelautan dan Kemiskinan Hingga Bajak Laut). Yogyakarta: Pustaka Pelajar.

Baswir, Revrisond. 2012. Koperasi Indonesia. Yogyakarta: BPFE.

Fahmi, Irham. 2011. Analisis Kinerja Keuangan. Bandung : Alfabeta.

Harahap, Sofyan Safari. 2009. Analisis Kritis dan Laporan Keuangan. Jakarta: PT Raja Grafindo Persada.

Hardingsih, 2013. Analisis Laporan Keuangan Dalam Menilai Kinerja Keuangan Pada Primer Koperasi Angkatan Darat (Primkoad) Kartika Benten di Balikpapan. Jurnal Ekonomi. Balikpapan: Universitas Mulawarman.

Hendar, Kusnadi. 2005. Ekonomi Koperasi. Jakarta: Fakultas Ekonomi. 2010. Manajemen Perusahaan Koperasi. Jakarta: Erlangga.

Hendrojogi, 2004. Koperasi Asas-Asas, Teori dan Praktek. Jakarta: PT. Raja Grafindo Persada.

Hery. 2015. Analisis Laporan Kaeuangan Cetakan Pertama. Yogyakarta: CAPS.

Kamar, Karmani. 2014. Analisis Kinerja Keuangan dan Tingkat Kesehatan Koperasi Simpan Pinjam. (Studi Kasus Pada KSP Al-Ihklas di Kota Makasar). Universitas Hasanudin.

Karsono, E. 2005. Mengenal Koperasi Indonesia. Bandung: CV Lestari.

Kasmir. 2011. Analisis Laporan Keuangan. Jakarta: Raja Grafindo Persada.

Manuhutu, Haris Nugrahi. 2017. Analisis Kinerja Keuangan dan Tingkat Kesehatan Koperasi Wanita Patra di Kota Dumai. Jurnal Online Mahasiswa Universitas Riau.

Munawir. 2017. Analisis Laporan Keuangan. Edisi Empat. Cetakan keempat belas. Yogyakarta: Liberty.

Munir dan Indarti. 2012. Analisis Tingkat Kesehatan Koperasi pada koperasi simpan pinjam "Cendrawasih" Kecamatan Gubug Tahun Buku 2011. Jurnal Kajian Akuntansi dan Bisnis STIE Widya Manggala.

Mutis, Thoby. 2001. Pengembangan Koperasi. Jakarta: PT. Gramedia.

Nurmala dan Yuniarti. 2013. Hubungan Kualitas Informasi Akuntansi Keuangan Syariah dengan Kinerja Keuangan Baitulmal Wattamwil (BMT) di kota Bandar Lampung. Jurnal ESAI Vol.7 No.1 Edisi Januari 2013. ISSN No. 19786034.

Putra, N.A.S. 2017. Analisis Tingkat Kesehatan Unit Simpan Pinjam KSU Tunas Muda Tahun 2015 Berdasarkan PerMen M.KUKM No. 14/Per/M.KUKM/XII/2009. Jurnal S1 Ak. Vol. 07, No. 01.

Putri, Yona Irfany. 2019. Analisis Kinerja Keuangan dan Tingkat Kesehatan Koperasi Simpan Pinjam (Studi Kasus Pada Koperasi Simpan Pinjam Anugrah Sari Desa Kalianget 
Kecamatan Seirit Kabupaten Buleleng Tahun 2015-2017. Jurnal Ilmiah. Universitas Pendidikan Ganesha, Vol. 10, No. 2.

Razak, Abd. Rahman, 2012. Ekonomi Koperasi dan UKM, Makasar: Penerbit Universitas Negeri Malang

Rudianto. 2013. Akuntansi Koperasi Edisi Kedua. Jakarta: Erlangga.

Simon, John. 2004. Bekerja Di Bank Itu Mudah. Jakarta: Gramedia Pustaka Utama.

Soedjono, Ibnoe. 2007. Membangun Koperasi Mandiri Dalam Koridor Jati Diri. Jakarta: LSP21-ISC.

Sudarwanto Ad enk. 2013. Akuntansi Koperasi Pendekatan Praktis Dan Penyusunan Laporan Keuangan. Graha Ilmu. Yogyakarta.

Sugiyono, Arief dan Untung, Edi. 2008. Panduan Praktis Dasar Analisa Laporan Keuangan. Jakarta: Grasindo.

Suryani, Tatik. 2008. Teknik Penyusunan Laporan Keuangan, Pelayanan Prima dan Pengelolaan SDM. Yogyakarta: Graha Ilmu.

Sutrisno. 2016. Manajemen Keuangan: Teori, Konsep dan Aplikasi. Yogyakarta: Ekonesia.

Syaifudin, Muhammad Imam. 2017. Analisis Tingkat Kesehatan Koperasi Simpan Pinjam di Kabupaten Rembang Tahun 2014-2015. Jurnal Profita Edisi 6.

Wibowo. 2007. Manajemen Kinerja. Jakarta: PT Raja Grafindo Parsada.

Widiyanti, Ninik. 2012. Koperasi. Edisi Kesembilan, Jakarta: Pt Rineka Cipta.

Menteri Negara Koperasi dan Usaha Kecil dan Menengah RI No. 06/Per/M.KUKM/V/2006. . No.20/Per/M.KUKM/XI/2008. .No.14/Per/M.KUKM/XII/2009. Pedoman Penilaian Kesehatan Koperasi Simpan Pinjam dan Unit Simpan Pinjam Koperasi.

Undang-Undang Republik Indonesia No. 25 Tahun 1992 Tentang Perkoperasian. 